\title{
In the Presence of the Living Cockroach: The Moment of Aliveness and the Gendered Body in Agamben and Lispector
}

\author{
EMMA R. JONES
}

In Clarice Lispector's 1968 novel The Passion According to G.H., a woman (G.H.) experiences an encounter with a cockroach that changes her perception of herself as a human being. ${ }^{1}$ Most of the novel is devoted to G.H.'s attempts to describe this encounter, which she describes as something like the "loss of [her] human constitution" (Lispector 6). The key to G.H.'s extraordinary reaction to the cockroach lies in the immense disturbance that she feels surrounding its "neutrality": the cockroach's pure aliveness is "bland," "without salt" (77). G.H., in short, is profoundly affected by the realization that the cockroach, as ancient, living matter, is "pre-human" and that, since she herself participates in this pure aliveness, her own humanity is a kind of put-on, a protective strategy or "third leg" (5), as she calls it. She states:

I was terrified by the raw truth of a world whose greatest horror is that it is so alive that for me to admit that I am as alive as it is - and my most hideous discovery is that I am as alive as it is-I shall have to raise my consciousness of life outside to so high a point that it would amount to a crime against my personal life. (14)

This new consciousness would amount to "a crime against [G. H.'s] personal life" because the life of the cockroach - the moment of pure aliveness-is stripped of particular qualities; it is "bland." As such it can no more be "G.H.'s" life than it can be "human" life. G.H. is disturbed 
by the horror and mystery of a moment of aliveness that precedes the human world and that threatens to undermine this world.

The Passion According to G.H. prefigures many of the issues recently raised by Giorgio Agamben in his The Open: Man and Animal (2002). Indeed, Agamben's concern with "bare life" is precisely a concern with this moment of "bland" aliveness that G.H. speaks of: it is a life without qualities, without classifications or projections. Moreover, Agamben argues, this "bare life" has, throughout Western history, been continually excluded from the human world. The "anthropological machine," a phrase which Agamben borrows from Furio Jesi, and which names the pre-reflective mechanism whereby the boundary between "human" and "animal" is negotiated, continually articulates and re-articulates this distinction, each time leaving "bare life" as an irreducible remainder (Agamben 26). The first remainder to be left over is, importantly, the body itself: in the first division within us of what is "human" from what is "animal," the body gets left behind as neither human nor animal but as a kind of life that is "irreducibly drawn and divided between animality and humanity" (12).

Agamben's critique of Heidegger's 1929-30 lecture course The Fundamental Concepts of Metaphysics further exposes this logic of the anthropological machine in its relation to embodiment. Agamben argues that Heidegger's discussion of Dasein as "world-forming" is based on an unrecognized "suspension and deactivation" (68) of animal life and indeed, of that animal life at the heart of Dasein's world: the body. This exploitative operation performed upon the body is the condition of possibility for the openness of the "human" world-the world that, in her encounter with the cockroach, G.H. feels slipping away. As a result of this analysis, Agamben suggests that the response necessary to halt the destructive motion of the anthropological machine cannot be "letting be"-since the disclosure of being is predicated upon 
an exploitation of life itself—but rather must consist in "[letting] be outside of being" (91). The suggestive final chapters of The Open focus on this new comportment, asking how we might approach the moment of aliveness without investing it either with qualities or with an inherent teleology. This is also G.H.'s task in attempting a response to her confrontation with the cockroach: she seeks a way to exist without "world-forming." However, in taking up Agamben's invitation to try to think an event of aliveness that resists all ontological categorization, an important question arises, namely: what role does the reification of an occurrence of embodiment into the opposed categories of "male" and "female" play in this logic of the anthropological machine? If, in fact, the man/woman opposition can be said to be at least as fundamental as the human/animal—as I will argue—what does this suggest about ontology?

In the first section of this paper, I offer an interpretation of Agamben's critique of Heidegger that focuses on the temporality implied in his discussion of bare life and of "letting be outside of being." I argue that the present moment itself is precisely what separates the human from the animal for Heidegger - it is precisely the place where bare life begs to be thought, and, furthermore, thought as embodiment. In the second section, I turn to Clarice Lispector's novel. The Passion According to G.H. provides both a helpful illustration of the above claims and segues into my discussion of gender. ${ }^{2}$ The third section deals in particular with this issue. Following Hélène Cixous' reading of Lispector's novel, I show that "woman," just as much as "animal," is a category that forms a constitutive outside to the world of the man/human. In fact, Agamben's understanding of the relationship between human and animal is, to some extent, analogous not only to Cixous' but also to Luce Irigaray's understanding of "the feminine" as that which enables the self-understanding of the "masculine" by its very exclusion. I thus briefly touch on the similarity between Agamben and Irigaray (which begs for much more extensive 
treatment), in order to illustrate the primary thesis of the paper: that if we hope to overcome the workings of the "anthropological machine," as Agamben suggests we should, we need to develop a new comportment toward life itself that eludes not only the distinction between human and animal, but also that between man and woman.

\section{Agamben's Critique of Heidegger: Embodiment and Time}

Heidegger contrasts “world-forming," the fundamental term of Dasein's specificity, with the "poverty in world" of the animal (Heidegger 176). The animal, Heidegger argues, is "captivated" by its environment and therefore can never achieve the distance required to grasp beings "as such": in other words, the animal can never perceive the ontological difference. As Matthew Calarco notes, Heidegger thus appears to lead us to a "dead end" in that it does not seem we can make any claim about the world of the animal that does not begin from within a disclosure that has been preemptively denied it (Calarco 26). In other words, Dasein encounters the animal as a result of its own "world-forming": we can "go-along-with" the animal because of the prior disclosure of a horizon of meaning to which the animal, as such, has no access (Heidegger 203). Thus, we can never encounter the animal on its own terms, for its "own terms" are constitutively determined to be alien to Dasein. Therefore, as Calarco notes, Heidegger makes it impossible to argue that in fact there may be an animal who does have the capacities he reserves for Dasein - the capacities for various ethical comportments made possible by the opening of "world." "One gets the sense," Calarco writes, "that any animal act that might indicate such a capacity would be quickly thrust aside by Heidegger and labelled as 'essentially different' from similar human acts" (26). Indeed, this is precisely the impasse we come to with Heidegger: he has always already inflected words like "comportment" in such a way that they 
could never apply to "the animal"; they are specific to Dasein by their very definition. How, then, are we to get around this impasse? Perhaps, as Agamben suggests, the key lies in the moment at which the worlds of the animal and of Dasein are seen, briefly, to coincide.

Agamben discovers this crucial moment of passage in the fundamental attunement of "profound boredom," to which the first part of Heidegger's course is dedicated. In the momentary similarity of animal captivation to profound boredom, Agamben sees the move that first inscribes the human/animal distinction, and that thereby opens up Dasein's "world." Heidegger describes the animal's "captivation" as a paradoxical openness to that which is nevertheless, in some sense, closed:

[T] he animal in its captivation is essentially held out in something other than itself, something that indeed cannot be manifest to the animal either as a being or as a nonbeing, but which, insofar as it disinhibits...brings an essential disruption...into the essence of the animal. (in Agamben 61)

This "disruption" serves the strategic function of allowing us to glimpse, for a moment, the passage between "human" and "animal;" for Heidegger describes "profound boredom," which he admits allows for Dasein's very world-forming, in nearly the same terms as he does animal captivation. In profound boredom Dasein experiences a deactivation of its possibilities, a kind of stepping-back from its projects and a paradoxical openness to a world which fails to claim its attention in any particular way. "But," as Agamben notes, "precisely for this reason, boredom brings to light the unexpected proximity of Dasein and the animal. In becoming bored, Dasein is delivered over...to something that refuses itself, exactly as the animal, in its captivation, is exposed...in something unrevealed" (65).

This point of proximity between Dasein and the animal is indeed fleeting, for precisely in the moment of the deactivation of Dasein's factical possibilities, the very possibilitization of its 
environment is revealed to it: in other words, in this moment, world itself is opened, and Dasein, rather than remaining in the moment of profound boredom or animal captivation, finds itself hurtling toward a future. Importantly, Agamben argues, this hurtling is only accomplished on the basis of a deactivation of our own animal life: that is to say, "Dasein...has awakened from its own captivation to its own captivation" (70). The "open" of Dasein's world is always and only an openness to the closedness of animal life. Therefore, Agamben argues, we can read "The Nothing" of Heidegger's "What is Metaphysics?" and the lethe of his later work as "suspended" versions of life itself: as life which has been reduced to a kind of nothingness (Agamben 69). In exposing this strategic reduction, Agamben negotiates Heidegger's impasse not by an empirical argument, but by investigating the mechanics of the distinction itself. But how exactly does this reduction, this operation work?

Note the temporality at play here: Dasein, I have said, instead of "remaining" in the present moment of life, finds itself "hurtling" toward a future. As William McNeill notes in his book The Time of Life, it is the uniquely projective character of Dasein's thrownness that makes world-formation possible. McNeill points out that what distinguishes Dasein from "the animal" in terms of time is that for Dasein "presence can only ever be a presence that has already been...future presence will always be a presence that will have been: with respect to the presence of what is present, [human beings] exist in an essential absence" (48). If we read Heidegger from Agamben's perspective, however, it is precisely this essential absence or void of the present that is the place where our own "animal life" is "suspended and deactivated" (Agamben 68). The reduction of the lived moment to a "void" which propels Dasein into the future and discloses its essence as an "already" or a "will-have-been" is the motor of the anthropological machine- the void of the present moment is the "abyss" between human and animal that Heidegger speaks of. 
According to Agamben's understanding of both Heidegger and (Kojève's reading of) Hegel, history itself is inaugurated by a separation of human from animal that, implicitly or explicitly, posits the achievement of "humanity" as a goal. In speaking about the opening of "world," Heidegger is thus already speaking about a projection beyond the "captivation" or nowness of the animal, one that furthermore uses this captivation as a foil for its own self-understanding. The very fact that Dasein is constantly said to be "elsewhere" thus bespeaks a kind of teleology, since this "elsewhere" denotes the place where the essence of humanity is to be revealed. This is why, for Agamben, we must be suspicious of the teleological projection, enacted within or upon our own bodies, that makes history itself (in its connection to this "ek-static" temporalization) possible.

For if, as Agamben argues, animal life or aliveness as such is necessarily located "outside of being," as the suppressed condition of the "open" of Dasein's world, then the crucial ethical response to animal life cannot be, as Heidegger's ontology would have it, "letting be," but rather, as we have said, we must seek a new kind of comportment: one that somehow allows for the occurrence of this present (embodied) moment, without the management of ontology or the projection of teleology. An attempt at this sort of comportment can perhaps be seen in G.H.'s response to her encounter with the cockroach.

\section{The Presence of the Living Cockroach}

G.H.'s story begins when she enters the room formerly inhabited by her maid, whom she has recently dismissed. Expecting to find it filthy and in need of cleaning, she is surprised to find the room impeccable, purely white, desert-like. Unnerved by the "dryness" of this room, and possessed by a sudden anger, G.H. indulges various vituperative fantasies of dousing it with 
water. As Rosi Braidotti points out in her reading of the novel, G.H. is beginning on a journey of "becoming-minoritarian," ${ }^{3}$ since she first crosses a class and race boundary in entering the space inhabited by her (black) maid. This journey will eventually proceed through a number of threshold-crossings that, according to Braidotti, lead her toward "the inhuman/the animal/the cosmic" (126). Indeed, Braidotti even speaks about G.H.'s "becoming-alive, in the manner of living matter" (128). This becoming-alive, becoming-life, then, begins with G.H.'s entrance into the desert-room. When she discovers life in this desert, in the form of the cockroach, she first tries to kill it by slamming the wardrobe door on it; but then, as a white paste oozes out of it, still alive, she is taken aback: “ “.. what I saw was life looking back at me. How else could I refer to that horrible, brute raw matter and dry plasma that was simply there... an ooze in which the roots of my identity were twisting about with intolerable slowness" (Lispector 49). It is G.H.'s shared "root" with the cockroach that perhaps horrifies her the most: the distressing discovery that her very identity is somehow connected with this primordial ooze. All the same, she is "seduced" by the cockroach, which, she feels, will somehow complete her entrance into this room (52). G.H.'s house is the topography of her human world, and this room is a subversive alcove that holds the ultimate secret: "That room," she says, "was the desert and therefore primitively alive. I had reached nothingness, and the nothingness was live and moist" (53).

That the ultimate inner core of the human world should be a "nothingness" that is not a nothingness, a nothingness that is "live and moist," corresponds to Agamben's thesis that Dasein's world is held open by virtue of "an operation enacted upon the not-open of the animal world" (Agamben 62). Furthermore, G.H. speaks about this pure aliveness in terms of a present moment that would not be subject to teleological projection, a moment of total immediacy: "I had never before realized that the moment of living too has no words. The moment of 
living...was becoming so 'now' that I was putting into my mouth the matter of life" (Lispector 71). The fear that G.H. experiences as correlated with this moment of aliveness is connected both to this immanent temporality and to the "blandness" I previously spoke of. "The moment of living is...Hellishly inexpressive" (71); "[i]t is a nothingness that...has no taste” (95). As such, it offers no promise of the human world, holds no potential for human meaning in its blandness, its indifference. It is the proof of what G.H. suspects, what she ultimately comes to accept and proclaim, when she says: "Listen, in the presence of the living cockroach: the worst discovery was that the world is not human, and that we are not human" (61).

To make the "crime" of this encounter complete, G.H. feels, she will have to taste this cockroach: in order to "get beyond [her] own life" (Lispector 161) she will have to eat the white paste that emerges from the cockroach's body: the neutral substance of life itself. Elena Carrera argues that this "heterophagous" desire to incorporate part of the body of the other is inevitable for G.H., since she has aligned the aliveness of the cockroach with God or the "big" Other. Since it is impossible to become this Other literally, Carrera argues, G.H.'s desire remains indebted to a kind of dialectical logic of inequality, whereby she must consume or subsume the "small" other, the cockroach. ${ }^{5}$ However, on the reading I have been developing, we should notice that it is not a question of "becoming" the other: in the opposition human/animal, for Agamben at least, what is at stake is the space between the two terms, the ways in which we might hold open this space, and the orientation toward obscurity—-toward life-that this would require. Precisely because we cannot sublate "life" into "world" or into a historical scheme, Agamben suggests that we must enter into a relationship with it as "unsavable." This requires a kind of "a-knowledge," or "forgiveness" (a play on the Latin ignoscere) of the "mystery" of life itself (Agamben 91). Agamben's description of Titian's portrayal of two lovers illustrates this "forgiveness": 
[I]n their fulfillment the lovers learn something of each other that they should not have known-they have lost their mystery-and yet have not become any less impenetrable.... These lovers have initiated each other into their own lack of mystery as their most intimate secret; they mutually forgive each other and expose their vanitas. Bare or clothed, they are no longer concealed or unconcealed-but rather, inapparent. (87)

If the process of concealment/unconcealment that, for Heidegger, marks the way in which Being gives itself to Dasein, can be aligned with a kind of sexual trajectory, then sexual fulfillment presents a case of the desoeuvrement or total worklessness of this scheme-a moment which has "gone beyond the difference between being and beings" (Agamben 92). In the "inapparence" of Titian's naked bodies, Agamben discovers a kind of "forgiveness": for sexual fulfillment, while in some sense grasping the mystery of life itself, ultimately "grasps" nothing: it is followed, perhaps, by relief, even by a kind of understanding, but certainly not by "knowledge." This confirms Agamben's suggestion that "the open" of world always attempts to bring to light only the very closedness of life itself. But what can we make of this provocative suggestion of Agamben's? What more is at stake in an attempt to experience the body as totally immanent or as simply "inapparent?"

\section{Immonde}

G.H.'s own "forgiveness" of mystery is perhaps first glimpsed when she speaks about the loss of "hope" necessitated by her encounter with the moment of pure aliveness. She speaks at first about "the courage to abandon hope" (50), and then, a few pages on, about a curious joy which she has begun to experience: “a joy without redemption...I don't know how to make it clear to you, but it was a joy without hope" (65). A joy "without redemption" is indeed an unsavable joy, an irredeemable remnant of life-a peculiar, immanent sensation, without 
teleological projection. This passage occurs directly following one to which Hélène Cixous devotes a considerable amount of attention, wherein G.H. reflects on the Bible's strictures regarding the "impurity" of those animals whose consumption it does not permit. Cixous' reflection on this passage, in her lecture "Birds, Women, and Writing," supports both my reading of The Passion According to G.H. along the lines of Agamben's analysis and introduces the importance of the question of gender in asking about that which lies "outside of being."

Cixous notes that the Portuguese word translated as "unclean" is immundo, from the Latin immundus. It is also immonde in French. What is "unclean," then, is actually "out of the mundus...the monde, the world, that is so-called clean. The world," in other words, "that is on the good side of the law ..." (117). We might add that this "world" can be aligned with the world Heidegger speaks of - for, as Agamben has shown, the disclosure of this world as horizon of meaning is in fact determined by the "law" of exclusion, the law of the anthropological machine. Furthermore, Cixous points out the pure formalism of this law. She writes: "So why are those birds imund? Because. As you know, this is the secret of the law: "because"' (117). This purely formal "because" is analogous to the equally pure formalism of the anthropological machine: for Agamben, "[h]omo sapiens is...neither a clearly defined species nor a substance; it is, rather, a machine or device for producing the recognition of the human" (26). Thus, the human being can never be anything other than its own self-definition: its own "because." Both Agamben and G.H., however, have discovered the secret of this law. Lispector writes (and Cixous translates): "And the law commands that whoever partakes of the imund, must do so without knowing; for, he who partakes of the imund knowing that it is imund, must also come to know that the imund is not imund. Is that it?" (qtd. in Cixous 116). The discovery that "the imund is not imund," seen in G.H.'s tentative tasting of the cockroach, is thus equivalent to the "forgiveness" of mystery. 
Recall Agamben's words: “[t]hese lovers have initiated each other into their own lack of mystery as their most intimate secret"- their mystery, that is, is not a mystery after all, in the sense that it no longer appears as something to be "solved." Rather, in their mutual "forgiveness" the lovers, Agamben suggests, render inoperative the "because" of the law—that same incessant movement that simultaneously defines and produces the human being.

But who exactly is the guardian of this law? Whom does it serve? The law, it seems, necessarily serves that which claims to be in the position of definability, unity or "rationality." For Agamben, the paradigmatic claim to identity is that of the "human" over against the "animal." However, this is not the case for Cixous and Lispector. For, as Cixous points out, it is the Bible that makes the law regarding the uncleanliness or "imund" character of cockroaches, bugs, birds, and other animals. And, for Lispector, the Bible is gendered: "What Clarice actually suggests is that the Bible is a masculine 'they.' One might [translate] it like this: 'Those HeBible, those Bible, they say everything" (Cixous 113). Not only animals, but women, Cixous suggests, are immonde (“[n]ot all women," she notes) (113). Nevertheless, the law which holds open "the world" is, for Cixous, a masculine one, and "[e]lsewhere, outside, birds, women, and writing gather" (113). This suggests that perhaps the constitutive move of Agamben's anthropological machine involves not only the opposition human/animal, from which all other oppositions and suspensions of alterity would follow, but the man/woman opposition as well.

The only mention of gender in Agamben's text comes in a quotation from Walter Benjamin, which indeed appears to follow this logic: "Sexual fulfillment delivers the man from his mystery...in it alone [the mystery] is severed—not solved. It is comparable to the fetters that bind him to life. The woman cuts them, and the man is free to die because his life has lost its mystery" (in Agamben 84). In this quotation we see the logic of "forgiveness" at work, but it is 
only the "man" who is in need of this forgiveness - the "woman" on this picture is aligned with the mystery itself. The "man," in other words, forgives only himself, and he uses the "woman" as an instrument of such forgiveness. But, if our analysis has been correct, he will then fail to stop the motion of the anthropological machine insofar as he still separates himself from the "woman," even—or maybe especially_in the act of sex. This confirms the suspicion that the separation between the sexes (to the benefit of the "man") is at least as deeply entrenched as the separation of "man" from animal. But what does this mean?

Given the conflation of masculinity with humanity, it seems that Agamben's anthropological machine is, in effect, an andrological ${ }^{6}$ machine: one that separates "man/human" from "everything else"- everything unfigurable, be it woman, animal, non-white person, monster, and so on. I am here drawing attention to the man/woman distinction in particular, not because I believe that sexual difference is always prior to or more important than other differences; but because, if the "human" is always already coded as male, we can and should view the man/woman dichotomy as a fundamental metaphysical boundary drawn at the edges of the human: in other words, as a particularly powerful delineation of what can (currently) be taken as meaningful within Dasein's world.

A brief comparison of Agamben's work with that of Luce Irigaray helps to elucidate this point. Irigaray, like Cixous and Lispector, understands the feminine as somehow situated outside the world of so-called "human" disclosure and discourse. Indeed, her early discussions of femininity have perhaps even more in common with Agamben's analysis than do Cixous', since for Irigaray, the "feminine" is explicitly doubled: on the one hand, it shows up within discourse as the specular, the unrepresentable, and on the other it constitutes an "outside" to (masculine) discourse. 7 Similarly, for Agamben, the "animal" shows up within the lethelaletheia scheme as 
captivation, as suspension, but it also exists "outside" as "bare life," the exclusion of which makes the opening of world possible. However, following Irigaray it would appear that the exclusion of the "feminine," the material, or "life" actually sets up binary sex categories themselves - since a sex can only claim to be "one" within the masculine discourse (which flees from materiality and aliveness). Thus, as Judith Butler has also noted, ${ }^{8}$ the emergence of the human is inextricably linked to the conferral of binary sex categories on a given body-and, according to Irigaray, both of these categories ("man" and "woman" as understood in patriarchal society) fail to think the feminine, which I am here aligning with embodiment and with Agamben's “bare life.”

Thus, to take some further cues from Irigaray, it appears that the "mirror" in which man must recognize himself in order to become human is not only the animal, but also woman, or the feminine. Women are, both literally and figuratively, "a machine or device for producing the recognition of the human"-figuratively because they are reduced to a mirroring function in discourse; literally because they are forced to reproduce the "recognition" of the human by bearing children (male children, preferably); and because this reproduction is conceived as mechanistic. ${ }^{9}$ Furthermore, the reduction of feminine specificity to a "mirror" or to a "machine" is analogous to the reduction of "life" to "nothingness." That is to say, it is also the reduction of feminine specificity to "nothingness" that makes possible the phallic scheme of discourse, which orients meaning by reference to binary oppositions. A disruption of this discourse would then also be at stake in Agamben's suggestion of immanent embodiment. Indeed, reading Agamben with Irigaray suggests that, just as we will have failed to think bare life if we continue to allow the anthropological machine to operate, we will also have failed to think sexual difference if we 
view it as necessarily binary, or as something which occurs only after the disclosure of human "world."

This final thought suggests that, for Irigaray at least, sexual difference is ontological and not ontic. But perhaps, as Agamben suggests with regard to life itself, a full revelation of sexual difference would have to pass beyond the ontic-ontological distinction. In fact, "sexual difference" thus understood perhaps connotes a disruption in Heidegger's "world-forming" scheme, a kind of jamming the brakes of disclosure itself in order to force a more considered reconciliation of the material and the spiritual-since, for Irigaray, the feminine material has been reduced to a kind of captivation or nothingness by the masculine "spiritual" or philosophical discourse. Such a reconciliation is certainly also at stake in Agamben's discussion, where the spiritual potential of the material (the animal) is erased by its limiting opposition to the properly "spiritual" (the human), as well as in G.H.'s encounter with the cockroach, where the cockroach itself is understood as "god"-in other words, as spiritualized matter. Thus, while according to Agamben it is enough to inhabit the space between "human" and "animal" life in order to retrieve the potentiality of aliveness-that is, the spirituality of matter-we have seen, through G.H.'s example as well as through Irigaray, that we must also try to inhabit the space between "man" and "woman," since these categories equally attempt to halt the experience of aliveness and to propel the destructive motion of the anthropological and andrological machine.

\section{Conclusion}

For Agamben, the division between human and animal propels the teleological motion of history, always taking place first within our own bodies. Heidegger's lecture course reveals the mechanics of the distinction whereby Dasein is said to be "world-forming" and historical only 
because of a prior "suspension" of its own animal life. Therefore, the "abyss" between human and animal is the "absence" of the present moment: it appears where the moment of living is reduced to "nothingness." Furthermore, this present moment of living is inseparable from the living materiality of the body. Clarice Lispector demonstrates this in her novel, where the "crime" of G.H.'s bodily communion with the cockroach lies precisely in the fact that she thereby reveals the mechanism of the "law" which separates, among other things, human from animal and which relegates pure aliveness to the immonde, the unworldly, or, as Agamben calls it, the "outside" of being. Because this law, moreover, is a masculine one, any attempt to think aliveness beyond the human/animal split must include an attempt to think the body in excess of the oppositional categories "male" and "female." The deep complicity of this division with the logic of the anthropological machine requires that we begin from a destabilization of these sexed unities, in order to free the life of the body from the management of ontology, which, Agamben suggests, is our most pressing task. ${ }^{10}$

\section{Notes}

${ }^{1}$ I would like to thank Frances Wood and the anonymous reviewer at PhaenEx for their helpful editorial suggestions concerning this article.

2 Because I am ultimately drawing an analogy between Agamben's analysis of the human/animal division and Irigaray's early understanding of the man/woman division, the traditional distinction between "sex" and "gender" does not seem to me to be appropriate to this discussion-the man/woman distinction becomes rather, as Agamben puts it (in reference to the human/animal split), "a fundamental metaphysico-political operation" (21). I use the term "gender" in this paper, therefore, not to draw a nature/culture distinction but to distinguish the designation of "man" and "woman" from "sex" in the sense of sexual intercourse, which Agamben does discuss.

${ }^{3}$ Borrowing the phrase from Deleuze and Guattari. See A Thousand Plateaus. 
${ }^{4}$ G.H. also refers to it as "the anti-sin" (Lispector 157).

${ }^{5}$ See Carrera, pgs. 126-139.

${ }^{6}$ This term was suggested to me by Ted Toadvine (personal correspondence, December 2006).

7 See Irigaray, "The Power of Discourse and the Subordination of the Feminine," and Judith Butler's reading in Chapter Two of Bodies that Matter.

${ }^{8}$ See Bodies that Matter and Undoing Gender.

${ }^{9}$ See Irigaray, “The Power of Discourse" and Speculum of the Other Woman.

${ }^{10}$ My thanks to Claudia Baracchi for helping me, through a course given in Spring 2005, to formulate Agamben's central thesis in precisely this way.

\section{Works Cited}

Agamben, Giorgio. The Open: Man and Animal, trans. Kevin Attell. Stanford: Stanford University Press, 2004.

Braidotti, Rosi. "Of Bugs and Women: Irigaray and Deleuze on the Becoming-Woman." Engaging with Irigaray. Ed. Carolyn Burke, Naomi Schor, and Margaret Whitford. New York: Columbia University Press, 1994. 111-141.

Butler, Judith. Bodies that Matter: On the Discursive Limits of "Sex." New York: Routledge, 1993.

—. Undoing Gender. New York: Routledge, 2004.

Carrera, Elena. "Heterophagous Passion: Eating the Other, Vomiting the Self." Inequality and Difference in Hispanic and Latin American Cultures. Ed. Bernard McGuirk and Mark I. Millington. New York: Edwin Mellen Press, 1995. 126-139.

Calarco, Matthew. "Heidegger's Zoontology." Animal Philosophy. Ed. Matthew Calarco and Peter Atterton. New York: Continuum, 2004. 18-31.

Cixous, Hélène. Three Steps on the Ladder of Writing. Trans. Sarah Cornell and Susan Sellers. New York: Columbia University Press, 1993. 
Deleuze, Gilles and Felix Guattari. A Thousand Plateaus. Trans. Brian Massumi. Minneapolis: University of Minnesota Press, 1987.

Heidegger, Martin. The Fundamental Concepts of Metaphysics: World, Finitude, Solitude. Trans. William McNeill and Nicholas Walker. Bloomington: Indiana University Press, 1995.

Irigaray, Luce. Speculum of the Other Woman. Trans. Gillian C. Gill. Ithaca: Cornell University Press, 1985.

—. This Sex Which is Not One. Trans. Catherine Porter with Carolyn Burke. Ithaca: Cornell University Press, 1985.

Lispector, Clarice. The Passion According to G.H. Trans. Ronald W. Sousa. Minneapolis: University of Minnesota Press, 1988.

McNeill, William. The Time of Life: Heidegger and Ethos. New York: SUNY Press, 2006. 